\title{
PEMANFAATAN LAHAN PEKARANGAN DENGAN TANAMAN OBAT KELUARGA
}

\author{
UTILIZING HOMEGARDEN WITH FAMILY MEDICINE PLANTS \\ ${ }^{1)}$ Umi Trisnaningsih, ${ }^{2}$ Siti Wahyuni, ${ }^{3)}$ Subandi Nur \\ ${ }^{1,2,3)}$ Program Studi Agroteknologi, Fakultas Pertanian Universitas Swadaya Gunung Jati (UGJ) \\ Jl. Pemuda no. 32 Cirebon 45132 \\ Email: umitrisna@gmail.com
}

\begin{abstract}
ABSTRAK
Ibu-ibu anggota TP - PKK Desa Gesik telah mengetahui tentang manfaat dari tanaman obat namun belum banyak yang membudidayakannya di lahan pekarangan mereka. Kegiatan ini dilaksanakan dengan tujuan meningkatkan keterampilan para ibu dalam budidaya tanaman obat di lahan pekarangan. Metode yang digunakan adalah pelatihan, yang terdiri dari penyuluhan, demonstrasi, dan pendampingan. Penyuluhan diikuti oleh 23 orang peserta sementara praktek diikuti oleh sepuluh orang peserta. Hasil kegiatan menunjukkan terjadi peningkatan pengetahuan dan minat peserta dalam budidaya tanaman obat.
\end{abstract}

Kata kunci: Lahan Pekarangan; Tanaman Obat; Tim Penggerak PKK

\begin{abstract}
The members of the PKK Team Gesik Village have learned about the benefits of medicinal plants, not many of which cultivate them in their yard. This activity was carried out with the aim of improving the skills of women in the cultivation of medicinal plants in the homegarden. The method used is training, which consists of extension, demonstration, and mentoring. Extension was attended by 23 participants, while ten participants participated. Results of the activity demonstrating the increased knowledge and interest of participants in the cultivation of medicinal plants.
\end{abstract}

Keyword: Homegarden; Medicine Plants; PKK Team

Submitted : 15 Juni $2019 \quad$ Revision : 16 Juli $2019 \quad$ Accepted : 20 Juli 2019

\section{PENDAHULUAN}

Masyarakat Indonesia sudah lama mengenal berbagai macam tumbuhan yang dapat dijadikan obat-obatan. Pengetahuan ini diwariskan secara turun temurun, dan merupakan bagian dari budaya mereka. Hasil penelitian Sari et al. (2015) menunjukkan bahwa menanam tanaman obat merupakan tradisi yang diwariskan secara turun temurun. Hal ini menunjukkan bahwa sumber informasi untuk pengetahuan tersebut adalah orang tua. Hasil penelitian di Desa Cibunar menunjukkan bahwa seiring dengan perubahan zaman, maka terjadi perubahan dalam sistem sosial dan ekonomi, termasuk pengetahuan tentang tanaman obat. Hal ini disebabkan karena generasi muda yang menguasai lagi bahasa lokal dan pengetahuan tentang obat tradisional juga semakin berkurang(Suryana \& Iskandar, 2014).

Perkembangan jumlah penduduk menyebabkan lahan yang biasanya ditanami tanaman obat telah berubah menjadi bangunan perumahan atau yang 
lainnya. Hal ini menyebabkan hilangnya habitat tanaman obat (Adiputra \& Handari, 2008). Selain itu, kemudahan akses ke tempat-tempat pelayanan kesehatan semakin mengurangi minat masyarakat terhadap pemanfaatan obatobat tradisional yang berbahan dasar tanaman. Oleh karena itu kesadaran masyarakat akan peranan tanaman obat bagi kesehatan perlu ditingkatkan. Dengan semakin meningkatnya pengetahuan masyarakat akan obat-obatan berbahan herbal, akan meningkatkan peluang usahatani tanaman obat-obatan.

Budidaya tanaman obatdapat dilakukan di pekarangan atau halaman rumah. Dengan demikian, selain sebagai tanaman obat keluarga (TOGA) juga dapat dijadikan usaha sampingan bagi para ibu rumah tangga.Lahan pekarangan memiliki potensi dalam penyediaan bahan pangan keluarga, mengurangi pengeluaran rumah tangga untuk pembelian pangan dan meningkatkan pendapatan rumah tangga (Saptana \& Purwantini, 2012), dan juga dapat dimanfaatkan untuk budidaya tanaman obat. Upaya meningkatkan kesadaran masyarakat untuk menanam tanaman obat di lahan pekarangan perlu disosialisasikan oleh Pemerintah. Tugas ini diberikan kepada Tim Penggerak PKK, melalui para kadernya (Susanto, 2017). Dengan semakin meningkatnya pengetahuan para kader, diharapkan dapat menyebarkannya kepada anggota masyarakat yang lainnya, sehingga kesadaran masyarakat untuk menanam tanaman obat di pekarangan akan meningkat.

Desa Gesik, Kecamatan Tengah Tani adalah salah satu desa yang berada di perbatasan antara Kabupaten dengan Kota Cirebon. Desa ini mempunyai karakteristik khas daerah urban, yaitu kondisi sosial ekonomi yang masih rendah, pemukinan cenderung padat dengan halaman rumah yang sempit. Pada umumnya mata pencaharian penduduk sudah tidak bertani tetapi di sektor industri atau usaha mikro, kecil dan menengah (UMKM). Sempitnya lahan pekarangan membuat penduduk Desa Gesik cenderung untuk tidak memanfaatkannya dengan baik. Padahal jika mengetahui teknik budidaya yang tepat, lahan sempit akanmemberikan manfaatyang besar.

Sosialisasi dan penyuluhan tentang pemanfaatan lahan pekarangan untuk tanaman obat keluarga (TOGA), akan meningkatkan pengetahuan masyarakat Desa Gesik, khususnya para ibu yang tergabung dalam Tim Penggerak Pembinaan Kesejahteraan Keluarga (TPPKK). Selanjutnya, para ibu tersebut akan terdorong untuk memulai pembuatan TOGA di halaman rumahnya. Sebagai kader PKK, para ibu ini juga diharapkan dapat menularkan pengetahuannya kepada ibu-ibu yang lain di wilayahnya. Dengan demikian, semakin banyak ibu yang menanam TOGA.

\section{METODE}

\begin{tabular}{lrr}
\multicolumn{2}{c}{ Metode yang digunakan adalah } \\
pelatihan dengan tujun untuk \\
meningkatkan pengetahuan dan
\end{tabular} keterampilan budidaya tanaman obat di pekarangan. Kegiatan ini terdiri dari dua kegiatan, yaitu penyuluhan dan demonstrasi teknik budidaya di Kebun Percontohan. Mitra kegiatan ini adalah ibu-ibu anggota Tim Penggerak PKK (TPPKK) Desa Gesik, Kecamatan Tengahtani, Kab. Cirebon, sebanyak 23 orang peserta. Pada kegiatan penyuluhan dilakukan survey berupa pre-test dan post-test. Uji t berpasangan digunakan untuk mengetahui ada tidaknya perbedaan pengetahuan antara sebelum dengan sesudah penyuluhan.

Demonstrasi teknik budidaya dilaksanakan di Kebun Percontohan, yang melibatkan seluruh peserta. Demonstrasi meliputi persiapan media tanam, persiapan bahan tanaman, penanaman dan pemeliharaan. Selama empat minggu setelah demonstrasi, dilakukan pendampingan dalam pemeliharaan tanaman. 


\section{HASIL DAN PEMBAHASAN}

Keberlanjutan program TOGA akan berhasil jika para peserta dapat memahami tentang teknik budidaya TOGA (Hikmat. et al. 2011). Oleh karena itu , tujuan kegiatan pengabdian ini adalah meningkatkan pengetahuan ibu-ibu anggota TP-PKK tentang budidaya tanaman obat di pekarangan. Jenis kegiatan dalam pengabdian ini terdiri dari penyuluhan dan praktek penanaman. Sebelum dilakukan penyuluhan, para ibu terlebih dahulu dievaluasi pengetahuannya tentang tanaman obat keluarga. Pada dasarnya, ibu-ibu anggota TP-PKK telah mengetahui tentang TOGA karena program ini merupakan kegiatan dari Kelompok Kerja (Pokja) 3 dan 4 TPPKK (Susanto, 2017).Namun demikian, sebagian besar peserta belum memahami teknik budidaya yang baik di lahan pekarangan. Penyuluhan dilaksanakan pada tanggal 30 Maret 2019, di Balai Desa Gesik, yang diikuti oleh 25 orang peserta termasuk Ketua TP-PKK Desa Gesik. Keikutsertaan ketua TP-PKK ini menjadi penting untuk keberlanjutan program karena ketua berperan sebagai motivator dan memecahkan masalah (Metalisa, Saleh \& Tjitopranoto 2014).

Penyuluhan dilakukan dengan metode ceramah dan dilanjutkan dengan diskusi. Materi penyuluhan terdiri dari pengertian tentang TOGA, jenis-jenis tanaman obat yang dapat dibudidayakan di lahan pekarangan, serta penanganan panen dan pasca panen. Setelah selesai penyuluhan dilakukan lagi wawancara untuk apakah ada peningkatan pengetahuan para peserta. Berdasarkan hasil Uji $t$ berpasangan antara hasil tes sebelum dengan sesudah penyuluhan, diperoleh nilai $\mathrm{t}=-1,893$ dan $\alpha=0,78$, yang lebih besar dari 0,05. Hal ini menunjukkan bahwa tidak terjadi peningkatan pengetahuan tentang TOGA setelah dilakukan penyuluhan. Hasil analisis statistik ini dapat dipahami karena peserta telah memperoleh pengetahuan tentang TOGA selama mereka menjadi anggota TP-PKK. Penyuluhan yang hanya dilakukan satu kali tidak akan berpengaruh nyata terhadap peningkatan pengetahuan mereka. Materi yang berupa teknik budidaya tanaman obat nampaknya belum dipahami dengan baik oleh para peserta. Padahal pengetahuan tentang budidaya tanaman obat akan membantu peserta dalam praktek budidaya tanaman. Hasil penelitian Metalisa, Saleh, and Tjitopranoto (2014) menunjukkan bahwa intensitas mengikuti penyuluhan akan berpengaruh terhadap upaya pemanfaatan lahan pekarangan.

Kegiatan berikutnya adalah praktek budidaya tanaman obat, yang dilakukan di Kebun Percontohan PKK Desa Gesik. Kegiatan ini dilakukan pada tanggal 6 April 2019 yang diikuti oleh sepuluh orang peserta. Berkurangnya jumlah peserta diduga karena dipengaruhi berbagai faktor, antara lain motivasi peserta. Peserta penyuluhan yang merasakan manfaat pengetahuan tentang teknik budidaya tanaman, akan mengikuti praktek budidaya ini. Namun sebaliknya, mereka yang menganggap kegiatan tidak ada manfaatnya, tidak akan mengikuti kegiatan praktek budidaya ini. Dalam kegiatan ini dilibatkan tujuh orang mahasiswa dari Program Studi Agroteknologi, Fakultas Pertanian UGJ, sebagai pendamping ibu-ibu peserta.

Peserta praktek dibagi menjadi beberapa kelompok dan setiap kelompok mempunyai peranan yang berbeda yaitu kelompok 1 pengisian media tanam ke polybag, kelompok 2 pindah tanam sereh, kelompok 3 pemindahan tanaman kunyit putih pada polybag, kelompok 4 pemindahan tanaman sirih merah pada polybag, kelompok 5 penanaman rimpang lengkuas pada polybag, kelompok 6 penanaman rimpang kencur, kelompok 7 penanaman rimpang jahe gajah, kelompok 8 pemindahan tanaman jahe merah. Seluruh peserta penanaman tanaman TOGA begitu bersemangat mengikuti setiap tahapan penanaman mulai dari persiapan tempat tanam yaitu polibag 
Umi Trisnaningsih, Siti Wahyuni, Subandi Nur Pemanfaatan Lahan Pekarangan Dengan Tanaman Obat Keluarga

dengan cara membuka, membalik dan melipat bagian atasnya, pencampuran media tanam yaitu tanah : sekam : pupuk kandang dengan perbandingan $1: 1: 1$. Pengetahuan tentang peranan media tanam untuk pertumbuhan tanaman perlu disampaikan kepada para peserta, karena media tanam merupakan salah satu faktor penting yang menentukan hasil tanaman (Fatimah \& Handarto 2008). Bibit yang sudah pindah tanam disimpan di tempat yang ternaungi paranet untuk menghindari penguapan karena tanaman yang baru pindah masih harus beradaptasi dengan lingkungan.

Dalam rangka pemeliharaan, dilakukan pembagian tugas di antara peserta praktek. Pemeliharan yang dilakukan meliputi penyiraman dan penyiangan. Untuk mengetahui perkembangan tanaman dilakukan kegiatan monitoring, yang dilaksanakan seminggu, sekali setiap hari Sabtu. Selama pelaksanaan monitoring juga dilakukan diskusi tentang budidaya tanaman obat. Hasil monitoring menunjukkan bahwa kegiatan ini berhasil dengan baik. Hal ini ditunjukkan dengan keberhasilan para peserta dalam memelihara tanaman. Pada demonstrasi, telah ditanam sebanyak 100 polybag. Dari jumlah tersebut, sekitar 88 polybag tumbuh dengan baik atau $88 \%$. Tanaman yang tidak tumbuh sebagian besar adalah jahe emprit. Namun tingkat partisipasi peserta demonstrasi lebih rendah dibandingkan dengan penyuluhan. Dari 23 peserta penyuluhan, hanya 10 orang yang mengikuti kegiatan demonstrasi dan pemeliharaan tanaman, atau sekitar $43 \%$.

\section{SIMPULAN}

Masyarakat di Desa Gesik, terutama para ibu anggota TP-PKK sudah mengetahui tentang tanaman obat keluarga (TOGA). Mereka umumnya menanam satu atau dua jenis tanaman di halaman rumahnya. Penyuluhan dan praktek budidaya TOGA meningkatkan pengetahuan mereka tentang jenis dan teknik budidaya tanaman obat sehingga mendorong minat mereka untuk memanfaatkan pekarangannya untuk budidaya tanaman obat.

\section{DAFTAR PUSTAKA}

Adiputra, I. N., \& Luh Made, I.S. H., (2008). Strategi Pelestarian Tanaman Obat Dalam Perspektif Budaya. Bumi Lestari Journal of Environtment 8 (1), 1-14.

Saptana, A., \& Purwantini, T.B., (2012). Potensi Dan Prospek Pemanfaatan Lahan Pekarangan Untuk Mendukung Ketahanan Pangan. Forum Penelitian Agro Ekonomi, 30 (1) 13-30.

Sari, I.D., Yuniar, Y., Siahaan, S., \& Syaripuddin. M., (2015). Tradisi Masyarakat Dalam Penanaman Dan Pemanfaatan Tumbuhan Obat Lekat Di Pekarangan. Jurnal Kefarmasian Indonesia 5 (2), 123-32.

Hikmat., A., Zuhud. E.A.M., Siswoyo., Sandra. E., \& Sari, R.K., (2011). Revitalisasi Konservasi Tumbuhan Obat Keluarga ( Toga ) Guna Meningkatkan Kesehatan Dan Ekonomi Keluarga Mandiri Di Desa Contoh Lingkar Kampus IPB Darmaga Bogor Jurnal Ilmu Pertanian Indonesia 16 (2), 71-80.

Metalisa, R., Saleh, A., \& Tjitopranoto, P., (2014). Peran Ketua Kelompok Wanita Tani Dalam Pemanfaatan Lahan Pekarangan Yang Berkelanjutan. Jurnal Penyuluhan 10 (2): 158-70.

Suryana, Y, and J Iskandar. (2014). Studi Pengetahuan Lokal Tanaman Obat Pada Agroekosistem Pekarangan Dan DInamika Perubahannya Di Desa Cibunar Kecamatan Rancakalong Kabupaten Sumedang Jawa Barat. Bionatura 15 (3), 203-9.

Susanto, A., (2017). Komunikasi Dalam 
Sosialisasi Tanaman Obat Keluarga

(Toga) Di Kecamatan Margadana.

Jurnal Para Pemikir 6 (1): 111-17. 